\title{
Pemberdayaan Ibu-Ibu Posyandu Untuk Pemanfaatan Buah Lokal Dalam Upaya Peningkatan Kualitas Kesehatan Ibu Hamil
}

\author{
Septia Andini, Nisa Najwa Rokhmah, Yulianita \\ Program Studi Farmasi, Fakultas MIPA - Universitas Pakuan \\ Email : septiaandini85@gmail.com
}

\begin{abstract}
ABSTRAK
Anemia dan tekanan darah tinggi menjadi salah satu penyakit penyerta selama kehamilan yang dapat meningkatkan resiko angka kematian ibu dan anak (AKI) dan setelah melahirkan penyakit tersebut memiliki prevalensi untuk tetap muncul pada beberapa ibu. Kedua penyakit penyerta tersebut dapat dicegah dan ditangani dengan konsumsi vitamin maupun obat secara teratur dan dengan melakukan pola hidup sehat. Salah satu gambaran pola hidup Ibu hamil di kelurahan Pakansari adalah cenderung memilih makanan dan minuman tanpa mempertimbangkan nilai gizi dan manfaatnya. Pola makan dan minum tersebut dapat memperburuk kondisi serta memicu timbulnya penyakit penyerta selama kehamilan. Tujuannya adalah untuk memberikan edukasi kepada ibu hamil mengenai manfaat buah untuk ibu hamil dan melakukan demo pembuatan makanan dan minuman berbahan dasar buah. Metode yang dilakukan dalam penelitian ini yaitu: melakukan observasi, memilih obyek pengabdian, mengumpulkan data obyek pengabdian, mengisi kesediaan mengikuti kegiatan pemeriksaan dini dan penyuluhan dengan mengisi kuisioner, melaksanakan kegiatan penyuluhan dan pelayanan kesehatan. Hasil penelitian ini menunjukan bahwa pengetahuan ibu hamil mengenai manfaat buah masih sangat kurang, kurangnya pengetahuan ibu hamil mengenai manfaat buah-buahan ini dapat menjadi penyebab hanya sekitar 50\% ibu hamil yang mengkonsumsi buah setiap hari dan pengetahuan tentang pengolahan buah masih sangat kurang berdasarkan hasil data kuisioner $85 \%$ mengkonsumsi buah dengan cara dimakan langsung.
\end{abstract}

Kata Kunci: Ibu Hamil, Buah-Buahan, Anemia, Tekanan Darah Tinggi

\section{PENDAHULUAN}

Status gizi merupakan ukuran keberhasilan untuk pemenuhan nutrisi untuk ibu hamil. Gizi ibu hamil merupakan nutrisi yang diperlukan dalam jumlah yg optimal untuk pemenuhan gizi ibu sendiri dan perkembangan janin yang dikandungnya (Haryani, 2013). Kebutuhan gizi semakin meningkat dengan bertambahnya usia kehamilan. Tambahan kebutuhan asupan energi selama trisemester 1 sebesar $180 \mathrm{kal}$, kemudian terjadi peningkatan pada trisemester II dan III sebesar 300 kal. Untuk menghindari defisiensi gizi selama kehamilan maka ibu hamil harus menjaga kondisi fisik dengan mencukupi kebutuhan gizi dengan cara mengkonsumsi makanan yang mengandung energi, protein, vitamin, lemak, mineral, serat dengan porsi yang seimbang (Febriana dan Ahmad 2014).

Penduduk Kelurahan Pakansari pada tahun 2018 berjumlah 43.628 jiwa terdiri dari jumlah penduduk laki-laki sebesar 22.129jiwa dan jumlah penduduk perempuan sejumlah 21.499jiwa dengan jumlah Kepala Keluarga 9713 KK. (Anonim, 2018) Hingga saat ini belum ada pendataan jumlah pasti ibu hamil di tingkat kelurahan Pakansari namun berdasarkan kegiatan pengabdian masyarakat yang dilakukan tahun 2019 diketahui pada lokasi kegiatan memiliki jumlah ibu hamil yang cukup banyak. 
Kelurahan Pakansari memiliki jumlah ibu hamil yang cukup tinggi. Dua RW yang ikut berpartisipasi pada kegiatan pengabdian masyarakat tahun 2019 menunjukkan bahwa dari $25 \mathrm{ibu}$ hamil diketahui bahwa $12 \%$ di antaranya memiliki kadar Hemoglobin di bawah normal yang menjadi salah satu indikator anemia selama kehamilan dan $40 \%$ di antaranya memiliki tekanan darah tinggi. (Rokhmah, 2019). Sebagian besar dari mereka tidak mengetahui kadar hemoglobin serta tekanan darah meskipun mereka mengakui melakukan pemeriksaan rutin ke bidan atau dokter. Konsumsi vitamin maupun obat selama kehamilan juga tidak dapat dijelaskan secara rinci oleh ibu hamil dan beberapa menyatakan minum obat/ vitamin tidak secara rutin (Subiyanto, 2012).

Anemia dan tekanan darah tinggi menjadi salah satu penyakit penyerta selama kehamilan yang dapat meningkatkan resiko angka kematian ibu dan anak (AKI) dan setelah melahirkan penyakit tersebut memiliki prevalensi untuk tetap muncul pada beberapa ibu (Latifah, dkk., 2017). Kedua penyakit penyerta tersebut dapat dicegah dan ditangani dengan konsumsi vitamin maupun obat secara teratur dan dengan melakukan pola hidup sehat. Salah satu gambaran pola hidup Ibu hamil di kelurahan Pakansari adalah cenderung memilih makanan dan minuman tanpa mempertimbangkan nilai gizi dan manfaatnya. Pola makan dan minum tersebut dapat memperburuk kondisi serta memicu timbulnya penyakit penyerta selama kehamilan

\section{Waktu Dan Lokasi}

Kegiatan penyuluhan dan pelayanan kesehatan dilakukan di dua RW di Kelurahan Pakansari yaitu RW 04 dan RW 10.

\section{METODE}

Metode yang dilakukan dalam penelitian ini yaitu : melakukan observasi, memilih obyek penelitian, mengisi kesediaan mengikuti kegiatan pemeriksaan dini dan penyuluhan dengan mengisi kuisioner melaksanakan kegiatan penyuluhan dan pelayanan kesehatan dan melakukan demo pembuatan makanan dan minuman berbahan dasar buah.

\section{HASIL DAN PEMBAHASAN}

\section{Karakteristik peserta kegiatan}

Peserta kegiatan pengabdian berjumlah 20 orang dari dua RW yang berbeda yaitu RW 04 dan RW 10. Karakteristik responden terdapat pada Tabel 1.

Tabel 1. Karakteristik Responden

\begin{tabular}{lcc}
\hline Keterangan & Jumlah & $\begin{array}{c}\text { Persentase } \\
(\boldsymbol{\%})\end{array}$ \\
\hline Rentang usia & & \\
17-25 (remaja akhir) & 5 & 25 \\
26-35 (dewasa awal) & 11 & 55 \\
36-45 (dewasa akhir) & 4 & 20
\end{tabular}




\section{Usia kehamilan}

\begin{tabular}{lcc}
$1-3$ bulan & 3 & 15 \\
$3-6$ bulan & 7 & 35 \\
$6-9$ bulan & 10 & 50 \\
\hline
\end{tabular}

Karakteristik ibu hamil peserta pengabdian masyarakat sebagian besar pada rentang usia dewasa awal (26-35 tahun). Usia ibu hamil terakit dengan banyak hal, usia 20-35 tahun dinyatakan sebagai usia yang tidak beresiko terhadap kehamilan karena usia tersebut wanita dinyatakan siap secara kondisi fisik selain itu rentang di bawah atau di atas usia tersebut memperbesar resiko abortus spontan (Subiyanto, 2012)

Sebanyak 50\% peserta sedang berada pada fase trimester terakhir. Makanan ibu hamil mempunyai peranan penting bagi tumbuh kembang janin dan pada saat ibu akan melahirkan. Banyaknya makanan yang dibutuhkan ibu hamil tergantung dari kondisi badan dan usia kehamilan ibu hamil. Pada trisemester 1 umur kehamilan 1-3 bulan awal kehamilan merupakan masa dimana sistem organ prenatal dibentuk dan mulai berfungsi Trisemester kedua berat janin bertambah bentuk tubuh bayi sudah dan perkembangan organ-organ juga terjadi. Pada trimester ketiga pertumbuhan makanan harus disesuaikan dengan keadaan badan ibu, untuk ibu hamil dengan berat badan berlebih mengurangi makanan dengan banyak lemak, dianjurkan untuk banyak mengkonsumsi makanan yang mengandung serat (Febriana, 2014).

\section{Karakteristik Penyakit Penyerta dan Keluhan Selama Kehamilan}

Kehamilan dibagi menjadi tiga trimester. Ketika memasuki trimester III atau umur kehamilan semakin bertambah, semakin banyak keluhan yang dirasakan oleh ibu. Perubahan ini tidak hanya berhubungan dengan perubahan fisik, namun juga perubahan biokimia, fisologis, bahkan psikologis yang merupakan konsekuensi dari pertumbuhan janin dalam rahim. Terjadinya perubahan pada ibu hamil ini untuk menjaga metabolisme tubuh, mendukung pertumbuhan janin, serta persiapan persalinan dan menyusui dengan tingkatan yang bervariasi di setiap trisemesternya. (Sukorini, 2017). Karakteristik penyakit penyerta dan keluhan selama kehamilan ibu hamil di Kelurahan Pakansari dapat dilihat pada Tabel 2.

Tabel 2. Karakteristik Penyakit Penyerta dan Keluhan Selama Kehamilan

\begin{tabular}{lcc}
\hline Keterangan & Jumlah & $\begin{array}{c}\text { Persentase } \\
(\%)\end{array}$ \\
\hline $\begin{array}{l}\text { Penyakit penyerta } \\
\text { Penyumbatan tuba }\end{array}$ & & \\
fallopi & 1 & 5 \\
Asma & 2 & 10 \\
Mag & 2 & 10 \\
Keluhan & & \\
Mual & 11 & 55 \\
Pusing & 1 & 5 \\
Nyeri punggung & 1 & 5 \\
Nyeri pinggul & 2 & 10 \\
\hline
\end{tabular}


Sebesar 55\% keluhan ibu hamil di Kelurahan Pakansari berupa mual. Mual merupakan salah satu keluhan yang umum terjadi selama kehamilan, terutama pada trimester pertama dan lama kelamaan akan berkurang frekuensi dan keparahannya seiring waktu kehamilan. Hal ini juga tidak perlu menjadi sebuah kekhawatiran berlebih selama ibu hamil tetap dapat mengkonsumsi dan menjaga asupan makanan dan cairan, terutama makanan dengan kandungan gizi dan vitamin yang baik seperti daging, sayur, dan buah. Hal yang perlu diwaspadai adalah apabila mual muntah menjadi semakin parah atau disebut dengan hipermesisgravidarum, kondisi ini menyebabkan mual muntah menjadi tidak terkendali sehingga volume cairan tubuh akan menurun dan melambatkan peredaran darah, kemudian menyebabkan pasokan oksigen dan nutrisi ke jaringan akan berkurang (Hidayati, 2009). Keluhan lainnya yang dinyatakan oleh ibu hamil adalah nyeri pinggang dan punggung, berdasarkan penelitian nyeri pinggang bagian bawah merupakan salah satu keluhan utama pada kehamilan terutama memasuki bulan ke 7 (Mafikasari dan Ratih, 2015). Hal ini dapat disebabkan oleh perubahan fleksibiltas otot seiring dengan perubahan berat badan dan beban (Wahyuni dan Prabowo, 2012) Penyakit penyerta yang diderita ibu hamil paling banyak adalah mag dan asma. Saat wawancara, ibu hamil menyatakan bahwa asma ini didapat setelah melahirkan anak pertama dan distimulasi jika cuaca dingin. Sedangkan keluhan terbanyak adalah mual muntah. Kondisi mual muntah atau dikenal dengan kondisi morning sickness hampir dialami oleh semua ibu hamil pada trisemester pertama kehamilan. Salah satunya disebabkan oleh hormon kehamilan dan juga karena kondisi psikologis ibu hamil itu sendiri (Latifah,dkk., 2017).

\section{Pola Konsumsi Buah Ibu Hamil}

Kecukupan kebutuhan nutrisi untuk perkembangan dan kesehatan ibu selama hamil memerlukan asupan makanan yang seimbang, yang mana pola makan seimbang itu terdiri dari berbagai asupan makanan dalam jumlah dan proporsi yang sesuai untuk memenuhi kebutuhan gizi seseorang. Asupan makanan yang tidak seimbangakan menyebabkan ketidakseimbangan zat gizi yang masuk kedalam tubuh.(Syari, dkk 2015) Mengkonsumsi buah merupakan bagian dari kebutuhan dasar ibu hamil untuk mencapai derajat kesehatan yang optimal. Konsumsi buah oleh ibu hamil di kelurahan pakansari dilakukan rutin, sebanyak 50\% mengkonsumsi buah setiap hari. Karakteristik ibu hamil terkait konsumsi buah di kelurahan Pakansari terdapat pada Tabel 2.

Tabel 2. Karakteristik ibu hamil terkait konsumsi buah

\begin{tabular}{lrr} 
Keterangan & Jumlah & Persentase \\
\hline Konsumsi Buah & & \\
Setiap hari & 10 & 50 \\
2-3 kali sehari & 3 & 15 \\
2-3hari sekali & 7 & 35 \\
Cara konsumsi & & \\
$\begin{array}{l}\text { Di jus dan dimakan } \\
\text { langsung }\end{array}$ & 1 & 5 \\
$\begin{array}{l}\text { Dimakanlangsung } \\
\begin{array}{l}\text { Pengetahuan mengenai manfaat buah } \\
\text { selama kehamilan }\end{array}\end{array}$ \\
$\begin{array}{l}\text { Sangat tahu } \\
\text { ( }\end{array}$ & \\
\end{tabular}




\begin{tabular}{lcc}
$\begin{array}{l}\text { Kurang tahu } \\
\text { Sumber informasi manfaat dan cara } \\
\text { mengolah buah }\end{array}$ & 85 \\
Penyuluhan & 2 & 10 \\
TV & 3 & 15 \\
Internet & 15 & 75 \\
\hline
\end{tabular}

Sebagian besar ibu hamil kurang mengetahui manfaat konsumsi buah selama kehamilan sehingga diharapkan melalui kegiatan ini peserta mendapatkan gambaran yang lebih jelas dan mendalam. Kurangnya pengetahuan ibu hamil mengenai manfaat buah-buahan ini dapat menjadi penyebab hanya sekitar 50\% ibu hamil yang mengkonsumsi buah setiap hari.

\section{KESIMPULAN}

1. Ibu hamil yang mengikuti pengabdian masyarakat sebanyak 20 orang dari dua RW yaitu RW04 dan RW 10, kebanyakan usia ibu hamil berada di usia dewasa (26-35 tahun) dengan usia kehamilan 6-9 bulan (trismester ketiga)

2. Pengetahuan ibu hamil mengenai manfaat buah masih sangat kurang. Kurangnya pengetahuan ibu hamil mengenai manfaat buah-buahan ini dapat menjadi penyebab hanya sekitar 50\% ibu hamil yang mengkonsumsi buah setiap hari.

3. Pengetahuan tentang pengolahan buah masih sangat kurang berdasarkan hasil data kuisioner $85 \%$ mengkonsumsi buah dengan cara dimakan langsung

\section{DAFTAR PUSTAKA}

Anonim. 2018.https://bogorkab.bps.go.id/

Haryani, D.F.2013. Hubungan Karakteristik Tingkat Konsumsi Energi, Tingkat Konsumsi Protein dan Frekuensi Periksa Kehamilan dengan Pertambahan Berat Badan Ibu Hamil Trisemester II. Jurnal Kedokteran Muhammadiyah. Vol.1 No.2.

Febriana, R dan Ahmad, S. 2014. Kebiasaan Makanan Sayur dan Buah Saat Kehamilan Kaitannya dengan Konsumsi Sayur dan Buah Anak Usia Prasekolah. Jurnal Gizi dan Pangan. Vol 9. No.2, p:133-138

Subiyanto, V. P. 2012. Cara Sehat dan Aman Menghadapi Kehamilan di Atas Usia 35 Tahun. Klaten: Cable Boo

Latifah, L., Nina, S., Eti, D.H. 2017. Efektivitas Self Management Module dalam Mengatasi Morning Sickness. Jurnal Keperawatan FIKes ONSOED. Vol.5, No.1, p: 10-18

Hidayati, R. 2009. Asuhan Keperawatan Pada Kehamilan Fisiologis dan Patologis. Jakarta

Wahyuni dan Prabowo, E. (2012). Manfaat Kinesio tapping Untuk Mengurangi Nyeri Punggung Bawah Pada Kehamilan Trimester Ke-3. Jurnal Kesehatan.Vol. 5, No. 2, p: 119 - 129.

Mafikasari, A., Ratih, I. K. (2015). Posisi Tidur dengan Kejadian Back Pain (Nyeri Punggung) PadalbuHamil Trimester III. Jurnal Surya. Vol. 07, No.02., p:26-28.

Rokhmah, NN., Septia, A., Yulianita. 2019. Deteksi dan Edukasi Anemia pada Ibu Hamil di Kelurahan Pakansari Cibinong Bogor. Prosiding. Seminar Nasional Perhibpa Pemanfaatan Bahan Alam sebagai Obat, Kosmetik dan Pangan Fungsional. ISBN: 978-602-72418-6-2 
Syari, M., Joserijal, S.,Ulvi, M. 2015. Peran Asupan Zat Gizi Makronutrien Ibu hamil terhadap Berat Badan Lahir Bayi di Kota Padang. Jurnal Kesehatan Andalas. Vol 4 No.3,.

Sukorini, M.U. 2017. Hubungan Gangguan Kenyamanan Fisik dan Penyakit dengan Kualitas Tidur Ibu Hamil di Trisemester III. The Indonesian Journal of Public Health. Vol. 12 No. 1, Juli 2017: 1-12 